\title{
高度技術提案型総合評価方式における 入札結果の現状分析
}

\author{
嵩 直人 1 -小澤 一雅 2 \\ 1正会員＼cjkstart鹿島建設株式会社＼cjkstart海外支店（干107-8348 東京都港区赤坂6-5-11） \\ E-mail: dake@kajima.com \\ 2フェロー会員 東京大学教授 大学院工学系研究科社会基盤学専攻(干113-8656 東京都文京区本郷7-3-1) \\ E-mail: ozawa@civil.t.u-tokyo.ac.jp
}

\begin{abstract}
本論文では，国土交通省発注工事における高度技術提案型総合評価方式（一般土木，鋼橋上部，及び PC）を対象に, 現状の入札競争状態を評価することを目的として, 平成 18 年度〜平成 22 年度公告分の入 札調書を基に，入札結果の傾向を分析した.

分析の結果, 入札結果の傾向には工種ごとに特徵があり, 一般土木のトンネル工事, シールド工事, 及 び PC においては, 調査基準価格未満における価格競争が生じており, 他工種に比べて価格勝負の要素が 強い入札競争状態であることが窺えた。 さらに，上記 3 工種においては，参加者数が他工種に比べて多く， かつ技術評価点の最高点と次点の比が他工種に比べて小さいという特徴があることを確認した.
\end{abstract}

Key Words : public procurement, comprehensive bidding evaluation method, technical proposal, statistical analysis, bidding result data

\section{1. はじめに}

高度技術提案型総合評価方式（以下，高度技術提案 型）は，標準型，簡易型と並ぶ国土交通省直轄工事にお ける総合評価方式の一分類である. 高度技術提案型の現 行制度は，平成 18 年 4 月に「公共工事における総合評 価方式活用検討委員会」（以下，活用検討委員会）より 出された提言「高度技術提案型総合評価方式の手続きに ついて」においてほぼ構築されている. 同提言において, 高度技術提案型は「民間企業の優れた技術を活用するこ とにより工事の価值の向上を目指寸もの」とされており， 今後も技術的な工夫の余地が大きい工事においては，そ の有效活用が期待されると考えられる.

しかしながら，活用検討委員会における議論において も「高度技術提案型で低入札が多発している理由は調べ ておく必要がある」との意見が出ているなど1)，その入 札競争において価格競争の要素が強くなっている可能性 を指摘する意見があるのも事実である.

落札価格の妥当性を調査基準価格を基準に一概に判断 することはできないが，高度技術提案型における入札競 争の現状を確認しておくことは，同方式をより良い制度 に変えるための検討資料として有効であると考えられる.
また, 総合評価方式の一類型であるWTO標準型総合 評価方式 (以下, WTO標準型) については, 入札価格 を調査基淮価格を下回らない範囲で調査基準価格に最も 近づけることを意図した応札行動，いわゆる「価格当て ゲーム」に陥っているとの指摘があり ${ }^{2)}$ ，その原因とし て，「施工体制確認型総合評価落札方式が適用されてい る」「参加者数を絞り込んでいない「「技術提案の自由 度が低い」という制度上の特徵が考えられる. WTO標 準型に比べて, 施工体制確認型の適用割合が小さく, 参 加者数が少なく, 技術提案の自由度も高い高度技術提案 型においてどのような入札競争状態にあるのかを調査す ることは, WTO標準型の改善を検討する上でも大いに 参考になるものと考えられる.

\section{2. 研究の目的と方法}

\section{(1) 研究の目的}

本研究は，国土交通省発注工事における高度技術提案 型総合評価方式を対象に，「どのような入札競争が行な われたか (入札競争状態)」，及び「どのような者が落 札者になったか（落札者情報）」といった入札結果を調 查し，その傾向を明らかにすることを目的とした. 
国土交通省発注工事を研究対象とした理由は，総合評 価方式は，現在，地方自治体等の公共工事入札において も広く採用されているが，その制度の基本となっている ものは国土交通省の総合評価方式であり，その在り方が 地方自治体等にも影響すると考えたためである.

なお, 本研究では, 法規, 通達, ガイドライン, 及び その運用方法等も含めた総合評価方式の実施方法を総括 して「制度」と表現した。

\section{(2) 研究の方法}

国土交通省の直轄工事においては，入札結果が記載さ れた入札調書が，同省のwebサイトにリンクされた入札 情報サービス（http://www.i-ppi.jp/search/web/index.htm）に おいて公開される.

入札調書には, 入札参加者名, 技術評価点, 入札価格, 落札者名, 予定価格, 調査基準価格等が記載されており, 「どのような入札競争が行なわれたか（入札競争状 態）」，及び「どのような者が落札者になったか（落札 者情報）」といった入札結果について，情報を得ること ができる.

本研究では，高度技術提案型適用工事の入札調書を統 計分析することで，入札結果の傾向を分析した．また， その傾向を相対的に評価するために，平成22年度公告の WTO標準型適用工事との比較も行なった.

\section{3. 本研究の特徵}

\section{(1) 既往研究の整理}

既往研究のうち入札調書の統計分析值を基に総合評価 方式の現状分析を行っているものを対象に，その研究対 象とした総合評価方式の類型を調査した.

木下（2006） 3)は，四国地方整備局における総合評価 方式の実運用を通して，同方式の運用改善に対する方法 論を考察しているが，簡易型のみを調査対象としている。 牧角，田中（2007） ${ }^{4)}$ ，及び牧角，田中（2008） ${ }^{5)}$ にお ける調査対象も総合評価方式適用工事ではあるが，工事 ランクによる分類を行なっており, 総合評価方式の類型 による区別はされていない.

金子ら（2008）のは，総合評価方式の類型ごとに入札 結果の傾向を分析しているが，高度技術提案型の調査対 象件数は1件であり，他類型と比べて分析項目も少ない 松村ら（2010） 77も，総合評価方式適用工事を調査対 象としているが，一般競争入札であるか否か等に着目し ており, 総合評価方式の類型による区別はしていない.

塚原ら（2010） ${ }^{8)}$ は，実施件数の調査については高度 技術提案型に対しても実施しているが，落札者情報の分 析等は標準型と簡易型のみを対象にしている.

\section{(2) 本研究の特徵}

既往研究において, 高度技術提案型を主な対象として 入札結果の傾向を分析している事例は見られなかった. 本研究においては，調査対象を高度技術提案型に絞っ ているという点, 調査件数が多い（53件）という点が既 往研究と違う特徵であり, 高度技術提案型の制度全体を 捉えた考察を行なった。

\section{4. 入札調書の統計分析}

\section{(1) 調査対象}

平成18年度〜平成22年度に公告された国土交通省の直 轄工事（港湾関係を除いた8地方整備局発注の工事）を 調査対象とした.

発注区分については，全体の適用件数が少ない高度技 術提案型においても適用件数が比較的多い「一般土木」

「鋼橋上部」「プレストレスト・コンクリート（以下， PC)」とした．他の発注区分として機械設備等の実績 もあるがその割合は少なく，上記3つの発注区分だけで 全体の約9割を占めている.

また，総合評価の方法には，除算式と加算式があるが， 上記条件で収集できた加算式適用工事が1件のみであっ たこと，及び評価方法の違うものを同じ入札環境として 取り扱うべきではないと考えたことより，本研究では除 算式のみを調査対象とした。

平成22年度公告分は，前述の入札情報サービスより収 集した. 平成18年度〜平成21年度公告分は，国土交通省 国土技術政策総合研究所の協力を得て収集し，1件を除 いて全件を収集した。

以上により収集した調査対象の件数は，表-1のとおり である。

\section{(2) 調査対象における総合評価方式の制度概要}

\section{a) 総合評価の方法}

除算式とは，技術評価点を入札価格で除した值を評価 值とする方式である. 総合評価方式（除算式）における 用語の定義は表-2のとおりである.

表-1 調査対象の件数

\begin{tabular}{|c|c|c|c|c|}
\hline \multirow{2}{*}{$\begin{array}{l}\text { 公告 } \\
\text { 年度 }\end{array}$} & \multicolumn{3}{|c|}{ 高度技術提案型 } & \multirow{2}{*}{$\begin{array}{c}\text { WTO } \\
\text { 標準型 }\end{array}$} \\
\hline & 一般土木 & 鋼橋上部 & PC & \\
\hline H18年度 & 6件 & 2件 & 6件 & - \\
\hline H19年度 & 11件 & 3件 & 2 件 & - \\
\hline H20年度 & 9件 & 1件 & 0 件 & - \\
\hline H21年度 & 3 件 & 1件 & 1 件 & - \\
\hline H22年度 & 8件 & 0 件 & 0 件 & - \\
\hline 小計 & 37件 & 7件 & 9件 & 73件 \\
\hline 合計 & & 53 件 & & 73件 \\
\hline
\end{tabular}


表-2 総合評価方式 (除算式) における用語の定義

\begin{tabular}{|c|c|}
\hline 評価值 & $\begin{array}{l}\text { 落札者を決定するための数值であり, 技術評 } \\
\text { 価点を入札価格で除した数值のこと. }\end{array}$ \\
\hline 技術評価点 & $\begin{array}{l}\text { 工事目的物の性能等の評価点数であり, 標準 } \\
\text { 点に加算点を加えた点数のこと. 施工体制確 } \\
\text { 認型の場合は, 技術評価点=標準点十加算点 } \\
\text { +施工体制評価点となる. }\end{array}$ \\
\hline 標淮点 & $\begin{array}{l}\text { 競争に参加するための最低限の要求を満たし } \\
\text { ている場合に付与する技術評価点を算出する } \\
\text { 際の基礎点のこと. 100点固定. }\end{array}$ \\
\hline 加算点 & $\begin{array}{l}\text { WTO標淮型・高度技術提案型では, 評価点 } \\
\text { の合計のこと. 評価点とは, 個々の評価項目 } \\
\text { において各競争参加者の技術力等に応じて与 } \\
\text { えられる得点のこと. }\end{array}$ \\
\hline $\begin{array}{l}\text { 施工体制 } \\
\text { 評価点 }\end{array}$ & $\begin{array}{l}\text { 総合評価方式に施工体制確認型を付して行な } \\
\text { う場合に技術評価点の一部に施工体制の評価 } \\
\text { として加える点数のこと. 品質確保の体制を } \\
\text { 審查要素として加味する. 最大 } 30 \text { 点. }\end{array}$ \\
\hline
\end{tabular}

出典 : 「関東地方整備局における総合評価落札方式の適用ガイ ドライン（平成22年度版）」を基に筆者作成

\section{b) 施工体制確認型総合評価落札方式の導入}

平成18年12月8日の通達「施工体制確認型総合評価落 札方式の試行について」により，入札説明書等に記載さ れた要求要件を実現できる確実性の高さに対して施工体 制評価点を与える施工体制確認型総合評価落札方式（以 下，施工体制確認型）が導入された．本通達においては， 加算点の設定範囲も，平成17年10月に設定された10～50 点から10〜70点に引き上げられた。 これらは，平成17年 度以降において特に顕著化してきたダンピング受注の防 止を目的としたものである.

調査対象とした53件のうち，施工体制確認型が適用さ れた件数は6件であり，その割合は11.3\%であった。

また，加算点の配点については，53件のうち通達前に 公告された11件の平均值は38.2点であったのに対し，通 達後に公告された42件の平均值は52.7点であった。

\section{c) 高度技術提案型の特徵}

高度技術提案型は，民間企業の優れた技術を活用する ことにより工事価值の向上を目指寸ものであり，競争参 加者に構造上の工夫や特殊な施工方法等を含む技術提案 を求める総合評価方式である．高度技術提案型の適用の 考え方に応じてI，II， III型の3分類があるが，発注者側 が標準案を持たない，浰においては施工方法だけでな く工事目的物の設計についても技術提案が求められる. 発注者が標準案を持つ亚型においても仮設設計について は技術提案が可能であり，施工方法の変更により工事目 的物の変更を伴う場合には工事目的物の変更も認められ ている，つまり，高度技術提案型適用工事を対象とした 入札結果の分析においては，入札金額見積の基礎になる 設計工事数量が入札参加者ごとに異なるという点に留意
表-3 分析項目

\begin{tabular}{|c|c|c|c|}
\hline \multicolumn{3}{|c|}{ 分析項目 } & 方法 \\
\hline \multirow{8}{*}{$\begin{array}{l}\text { 入 } \\
\text { 札 } \\
\text { 競 } \\
\text { 争 } \\
\text { 状 } \\
\text { 態 }\end{array}$} & \multirow{5}{*}{ 参加者数等 } & 参加者数 & \multirow{5}{*}{ 平均 } \\
\hline & & 無効者数 & \\
\hline & & 不参加・辞退者数 & \\
\hline & & 予定価格超過者数 & \\
\hline & & 有効参加者数 & \\
\hline & \multirow{2}{*}{ 技術評価点分布 } & 1位が複数者いるケース & 割合 \\
\hline & & 最高点／次点 & \multirow{5}{*}{ 平均 } \\
\hline & 入札価格分布 & 最高価格／最低価格 & \\
\hline \multirow{6}{*}{$\begin{array}{l}\text { 落 } \\
\text { 札 } \\
\text { 者 } \\
\text { 報 }\end{array}$} & \multirow{3}{*}{ 落札率等 } & (a)落札率 & \\
\hline & & (b)調査基淮価格率 & \\
\hline & & (a)-(b) & \\
\hline & \multirow{3}{*}{ 落札者分類 } & 技術評価点1位 & \multirow{3}{*}{ 割合 } \\
\hline & & 最低価格 & \\
\hline & & 調査基準価格未満 & \\
\hline
\end{tabular}

しなくてはならない. また，予定価格についても，「技 術評価点の最も高い技術提案に基づき予定価格を算定す ることを基本とする」とされており，発注者側の標準案 に対する積算から予定価格が算定される他の総合評価方 式（簡易型，標準型）と異なる特徵を持つ. 予定価格を 基に算定される調査基準価格を分析指標として用いる場 合には，上記特徵に留意する必要がある.

\section{(3) 分析項目}

分析項目は表-3のとおりとした.

まず，競合状況を表す指標として，参加者数等を分析 項目とした.

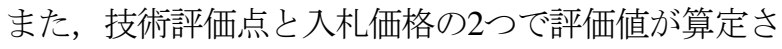
れる総合評価方式において，技術評価点と入札価格のそ れぞれが落札者の決定に対してどの程度影響を与えてい るのかを分析する指標として，「技術評価点1位が複数 者いるケースの割合」「最高点次点」「最高価格/最低 価格」を分析項目とした.

「最高点/次点」と「最高価格/最低価格」を指標とした 理由は，「（技術評価点 $\mathrm{A} / 入$ 札価格A）>（技術評価点 $\mathrm{B} /$ 入札価格B $) 」 \Leftrightarrow \Gamma($ 技術評価点 $\mathrm{A} /$ 技術評価点B $)>$ (入札価格 $\mathrm{A} /$ 入札価格B）」という計算式が成り立つこ とに着目すると，（最高点/次点）と（最高価格/最低価 格）の比較により，最高点を獲得することが落札者決定 に対してどの程度効いているのかをある程度把握できる と考えたからである. 例えば，（最高点/次点）>（最 高価格/最低価格）であった場合，最高点獲得者が最高 価格であり，次点獲得者が最低価格であったとした場合 でも，最高点獲得者が落札者となることになり，技術評 価点で最高点を獲得することの優位性が非常に高い状態 と言える.このような極端な例でなくても，（最高点/ 
次点）と（最高価格/最低価格）の相対関係を確認する ことで，最高点を獲得することが落札者決定に対してど の程度効いているのかを評価できると考えた．

落札者分類における「技術評価点1位の割合」「最低 価格の割合」についても，同様に，落札者決定に対して 技術評価点と入札価格のどちらの支配性が強いかを示寸 指標として分析項目とした.

また，価格競争の激しさの度合いを示す指標として， 落札率を調查基準価格率に対して相対化した「落札率一 調査基準価格率」を分析項目とした. 高度技術提案型に おいては，入札金額見積の基礎となる設計工事数量が入 札参加者ごとの技術提案内容に応じてそれぞれ異なるこ と，及び予定価格も基本的に技術評価点の最も高い技術 提案に基づき算定されるという特徴があるため, 調査基 準価格を基準に落札価格の妥当性までを一概に判断する ことはできないが，同じ高度技術提案型を適用された工 事における年度ごと，及び発注区分ごとの差異を確認す ることで, 入札競争状況の特徵を分析することができる と考えた.

\section{(4) 分析方法}

分析方法は, 分析項目ごとに対象データの平均值を算 出したものと, 分析項目に該当する件数が対象データの 全件数に占める割合を算出したものの2通りである. 平 均值の算出において，「最高点/次点」等，分析項目自 体に計算が伴うものは，1件ごとに計算した後にその計 算值を平均した.

有効参加者とは, 参加者から無効者, 不参加 - 辞退者, 及び予定価格超過者を除いた者のこととし，有効参加者
のみ総合評価を受ける対象となっている.

参加者数等以外の分析項目における分析対象は, 有効 参加者のみとした。例えば，入札調書には予定価格超過 者の入札価格も載っているが, 最高価格は有効参加者中 の最高価格とし, 予定価格超過者の入札価格は除いた.

技術評価点分布における次点とは，最高点を獲得した 者が1者の場合は2位の点数, 最高点を獲得した者が複数 者の場合は1位タイグループの次の点数とした.

また，「最高点/次点」，及び「最高価格/最低価格」 は, 有効参加者数が1者のみの場合は意味をなさない項 目であるため, 有効参加者が1者のみのケースは調査対 象から除外した.

\section{(5) 分析結果}

統計分析値の結果を表-4，5，6，7亿示す.

表-4は，公告年度ごとに分析結果を整理したものであ る. 分析対象は有効参加者数 1 者のみのケースを含めた 全件とした. 表-5は，発注区分ごとに分析結果を整理し たものである. 分析対象は有効参加者数 1 者のみのケー スを含めた全件とした．発注区分のうち一般土木につい ては, トンネル, ダム等の工種による分類も行なった.

表-6も，発注区分ごとに分析結果を整理したものである が，分析対象は有効参加者2者以上のケースのみとした. よって, 有効参加者数 2 者以上の場合にのみ意味をなす 「最高点/次点」, 及び「最高価格/最低価格」を分析項 目に入れた. WTO標準型の分析結果は，第5章の表-7に 整理した. WTO標準型は, 調査対象の全件で有効参加 者数2者以上であった.

表-4 高度技術提案型の工事公告年度ごとの統計分析結果（全件対象 : 53件）

\begin{tabular}{|c|c|c|c|c|c|c|c|c|}
\hline \multirow{2}{*}{\multicolumn{2}{|c|}{ 分析項目 }} & \multicolumn{6}{|c|}{ 統計分析值 } & 統計分析 \\
\hline & & $\begin{array}{c}\text { H18年度 } \\
\text { (14件) }\end{array}$ & $\begin{array}{c}\text { H19年度 } \\
\text { (16件) }\end{array}$ & $\begin{array}{c}\text { H20年度 } \\
\text { (10件) }\end{array}$ & $\begin{array}{c}\mathrm{H} 21 \text { 年度 } \\
\text { (5件) }\end{array}$ & $\begin{array}{c}\text { H22年度 } \\
\text { (8件) }\end{array}$ & $\begin{array}{l}\text { 全期間 } \\
\text { (53件) }\end{array}$ & 方法 \\
\hline \multirow{5}{*}{ 参加者数等 } & 参加者数 & 4.5者 & 5.3者 & 3.7者 & 4.4者 & 7.9者 & 5.1者 & \multirow{5}{*}{ 平均 } \\
\hline & 無効者数 & 0.1 者 & 0.1 者 & 0.1 者 & 0.4 者 & 2.3者 & 0.5 者 & \\
\hline & 不参加 - 辞退者数 & 0.4 者 & 0.1 者 & 0.0 者 & 0.0 者 & 0.0 者 & 0.1 者 & \\
\hline & 予定価格超過者数 & 0.6 者 & 1.3者 & 1.5者 & 0.8 者 & 0.6 者 & 1.0者 & \\
\hline & 有効参加者数 & 3.4者 & 3.8者 & 2.1者 & 3.2者 & 5.0 者 & 3.5者 & \\
\hline 技術評価点分布 & 1位が複数者のケース & $0.0 \%$ & $12.5 \%$ & $0.0 \%$ & $0.0 \%$ & $12.5 \%$ & $5.7 \%$ & 割合 \\
\hline \multirow{3}{*}{ 落札率等 } & (a)落札率 & $80.6 \%$ & $82.5 \%$ & $90.7 \%$ & $92.0 \%$ & $83.2 \%$ & $84.5 \%$ & \multirow{3}{*}{ 平均 } \\
\hline & (b)調査基準価格率 & $79.4 \%$ & $79.1 \%$ & $82.3 \%$ & $82.6 \%$ & $84.5 \%$ & $80.9 \%$ & \\
\hline & (a)-(b) & $1.2 \%$ & $3.3 \%$ & $8.4 \%$ & $9.4 \%$ & $-1.3 \%$ & $3.6 \%$ & \\
\hline \multirow{3}{*}{ 落札者分類 } & 技術評価点1位 & $50.0 \%$ & $50.0 \%$ & $80.0 \%$ & $80.0 \%$ & $75.0 \%$ & $62.3 \%$ & \multirow{3}{*}{ 割合 } \\
\hline & 最低価格 & $92.9 \%$ & $81.3 \%$ & $90.0 \%$ & $60.0 \%$ & $50.0 \%$ & $79.2 \%$ & \\
\hline & 調査基淮価格未満 & $50.0 \%$ & $25.0 \%$ & $10.0 \%$ & $0.0 \%$ & $37.5 \%$ & $28.3 \%$ & \\
\hline
\end{tabular}


表-5 高度技術提案型（全期間分）の発注区分ごとの統計分析結果（全件対象 : 53件）

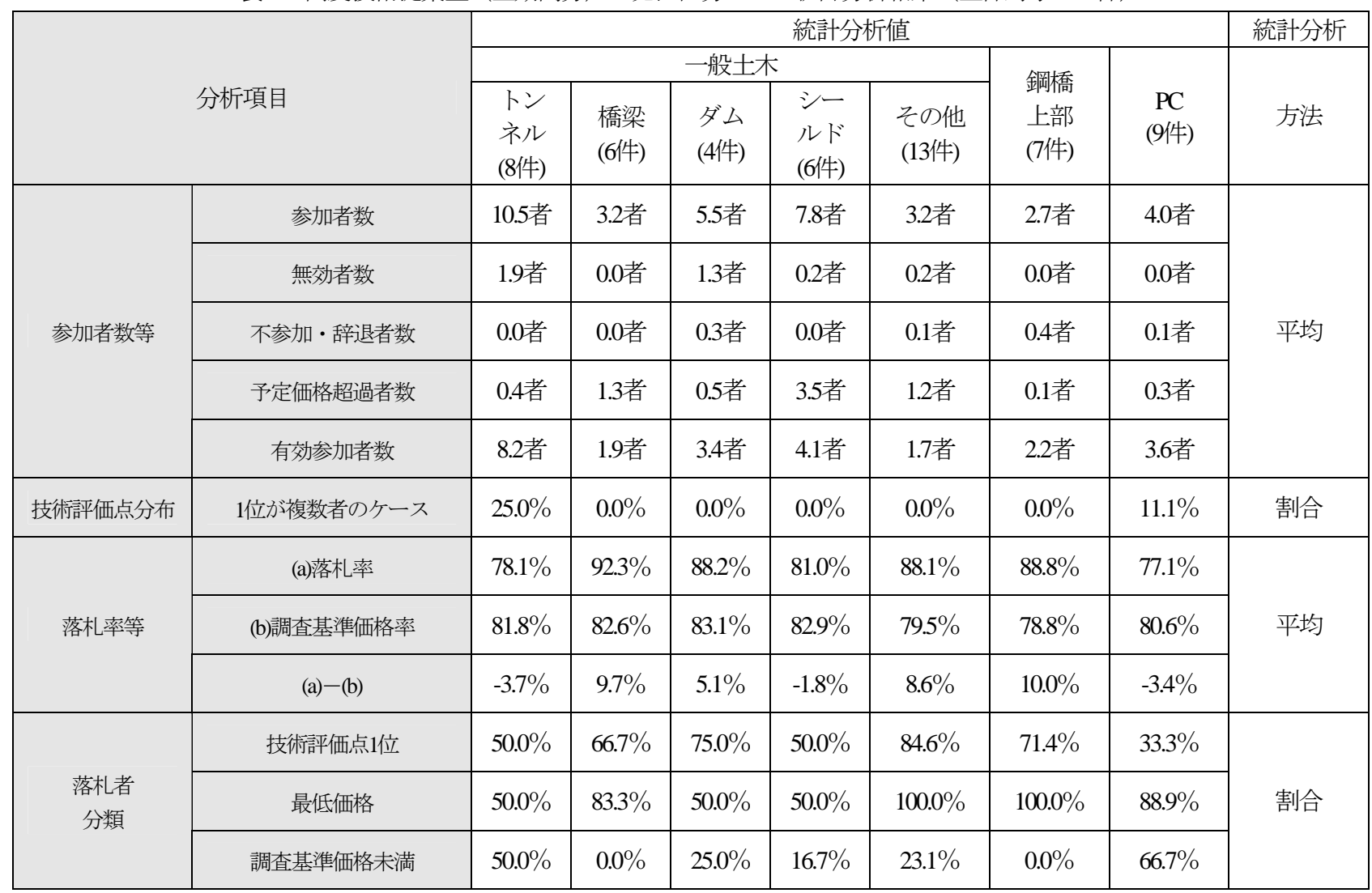

表-6 高度技術提案型（全期間分）の発注区分ごとの統計分析結果（有効参加者2者以上の工事を対象 : 38件）

\begin{tabular}{|c|c|c|c|c|c|c|c|c|c|}
\hline & \multirow[b]{3}{*}{ 析項目 } & \multicolumn{7}{|c|}{ 統計分析值 } & \multirow{3}{*}{$\begin{array}{c}\text { 統計分析 } \\
\text { 方法 }\end{array}$} \\
\hline & & \multicolumn{5}{|c|}{ 一般土木 } & \multirow[b]{2}{*}{$\begin{array}{c}\text { 鋼橋 } \\
\text { 上部 } \\
\text { (4件) }\end{array}$} & \multirow[b]{2}{*}{$\begin{array}{c}\text { PC } \\
\text { (9件) }\end{array}$} & \\
\hline & & $\begin{array}{l}\text { トン } \\
\text { ネル } \\
\text { (8件) }\end{array}$ & $\begin{array}{l}\text { 橋梁 } \\
\text { (2件) }\end{array}$ & $\begin{array}{l}\text { ダム } \\
\text { (3件) }\end{array}$ & $\begin{array}{l}\text { シー } \\
\text { ルド } \\
\text { (6件) }\end{array}$ & $\begin{array}{c}\text { その他 } \\
\text { (6件) }\end{array}$ & & & \\
\hline \multirow{5}{*}{ 参加者数等 } & 参加者数 & 10.5者 & 5.5者 & 7.0者 & 7.8者 & 4.5者 & 3.8者 & 4.0 者 & \multirow{5}{*}{ 平均 } \\
\hline & 無効者数 & 1.9者 & 0.0 者 & 1.7者 & 0.2 者 & 0.3 者 & 0.0 者 & 0.0 者 & \\
\hline & 不参加・辞退者数 & 0.0 者 & 0.0 者 & 0.3 者 & 0.0 者 & 0.2 者 & 0.5 者 & 0.1 者 & \\
\hline & 予定価格超過者数 & 0.4 者 & 2.0 者 & 0.7者 & 3.5者 & 1.3者 & 0.3 者 & 0.3 者 & \\
\hline & 有効参加者数 & 8.2者 & 3.5者 & 4.3者 & 4.1者 & 2.7者 & 3.0者 & 3.6者 & \\
\hline \multirow{2}{*}{ 技術評価点分布 } & 1位が複数者のケース & $25.0 \%$ & $0.0 \%$ & $0.0 \%$ & $0.0 \%$ & $0.0 \%$ & $0.0 \%$ & $11.1 \%$ & 割合 \\
\hline & 最高点 /次点 & 1.033 & 1.036 & 1.078 & 1.047 & 1.101 & 1.102 & 1.045 & \multirow{5}{*}{ 平均 } \\
\hline 入札価格分布 & 最高価格／最低価格 & 1.159 & 1.199 & 1.134 & 1.248 & 1.073 & 1.158 & 1.149 & \\
\hline \multirow{3}{*}{ 落札率等 } & (a)落札率 & $78.1 \%$ & $83.8 \%$ & $85.6 \%$ & $81.0 \%$ & $87.8 \%$ & $84.1 \%$ & $77.1 \%$ & \\
\hline & (b)調査基準価格率 & $81.8 \%$ & $81.1 \%$ & $83.3 \%$ & $82.9 \%$ & $80.6 \%$ & $79.4 \%$ & $80.6 \%$ & \\
\hline & (a)-(b) & $-3.7 \%$ & $2.7 \%$ & $2.4 \%$ & $-1.8 \%$ & $7.1 \%$ & $4.7 \%$ & $-3.4 \%$ & \\
\hline \multirow{3}{*}{$\begin{array}{c}\text { 落札者 } \\
\text { 分類 }\end{array}$} & 技術評価点1位 & $50.0 \%$ & $0.0 \%$ & $66.7 \%$ & $50.0 \%$ & $66.7 \%$ & $50.0 \%$ & $33.3 \%$ & \multirow{3}{*}{ 割合 } \\
\hline & 最低価格 & $50.0 \%$ & $50.0 \%$ & $33.3 \%$ & $50.0 \%$ & $100.0 \%$ & $100.0 \%$ & $88.9 \%$ & \\
\hline & 調査基淮価格未満 & $50.0 \%$ & $0.0 \%$ & $33.3 \%$ & $16.7 \%$ & $33.3 \%$ & $0.0 \%$ & $66.7 \%$ & \\
\hline
\end{tabular}




\section{5. 統計分析結果に対する考察}

\section{(1) 公告年度ごとの傾向}

表-4を基に，公告年度ごとの分析結果の推移をグラ フ化すると図-1，2，3のとおりとなる.

各指標とも，年度ごとに值が大きくなったり小さく なったりしており，一定の傾向が見られない。これは， 年度ごとの対象件数が5〜16件と少ないために, 各年度 ごとの発注区分の偏りや特異值の影響を受け易いこと によるものだと考えられる．例えば，平成22年度に参 加者数が急増しているのは，その年に公告された駟馳 山バイパス細川トンネルで参加者数が26者と他工事に 比べて極端に多かったことが影響している.

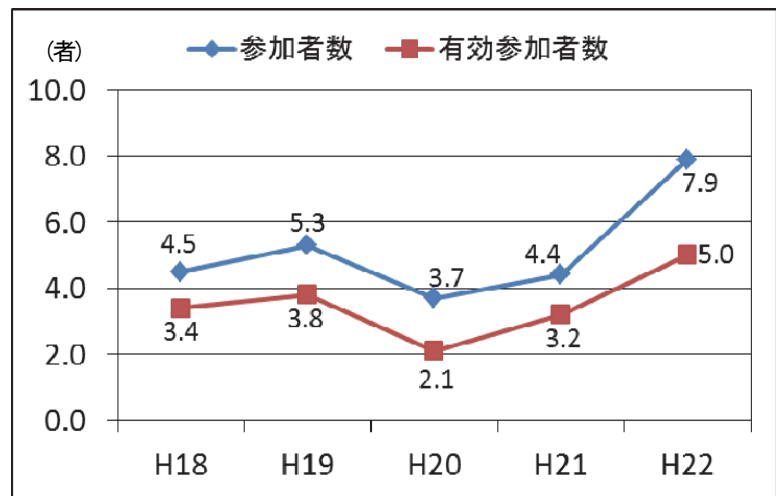

図-1 参加者数, 及び有効参加者数の推移

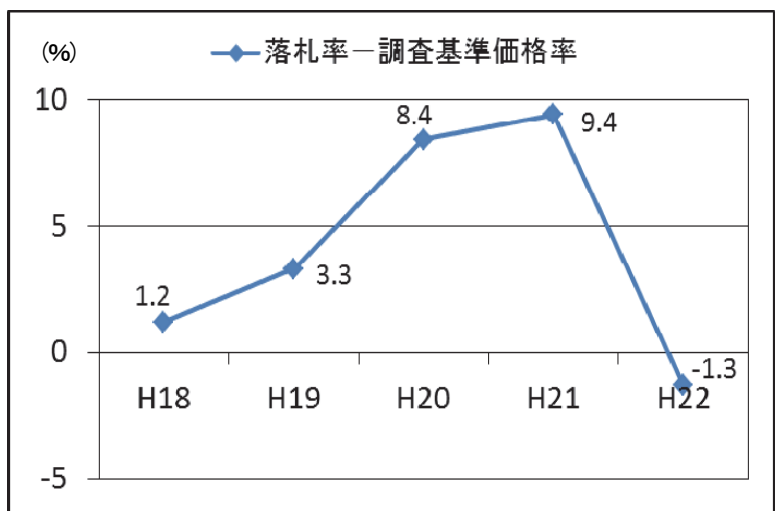

図-2（落札率一調査基準価格率）の推移

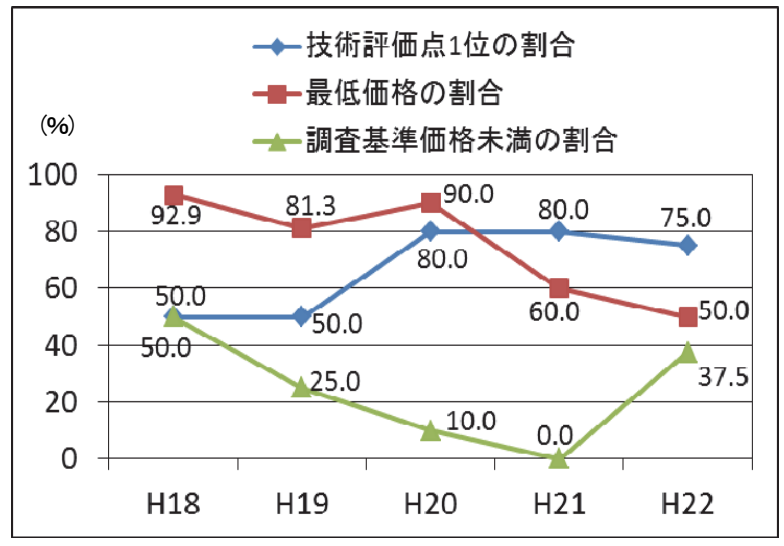

図-3 落札者分類の割合の推移

\section{(2) 発注区分ごとの傾向}

表-5を基に，発注区分ごとの分析結果をグラフ化す ると図-4，5，6のとおりとなる.

各指標とも発注区分ごとに大きな差があることが分 かる．参加者数については，トンネル工事が10.5者と特 に多いことが分かる（前述の駟馳山バイパス細川トン ネルの26者を除いても，平均8.3者である）。

また，参加者数が4.0者以上の 4 工種（トンネル，ダム， シールド，PC）のうちダムを除いた3工種は（落札率一 調查基準価格率）の平均值がマイナスになっており， 参加者数と（落札率一調査基準価格率）の間に一定の 関係があることが窥える。

（落札率一調査基準価格率）と落札者分類の割合を 比べると，（落札率一調查基準価格率）が特に低い卜

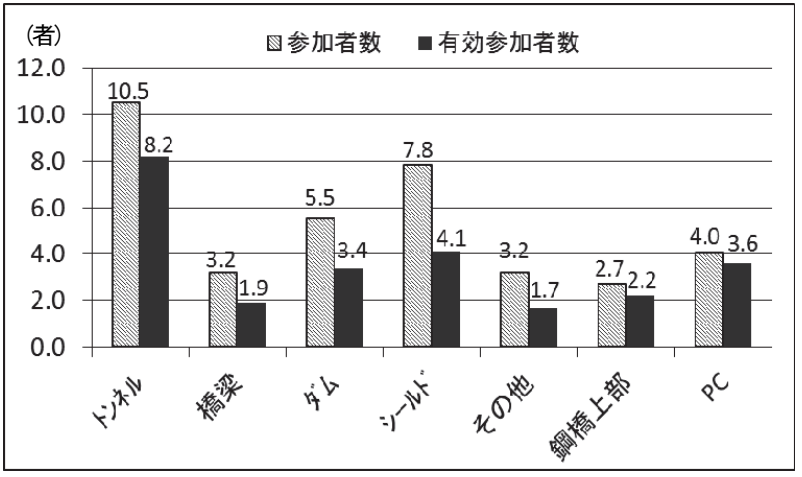

図-4 発注区分ごとの参加者数，及び有効参加者数

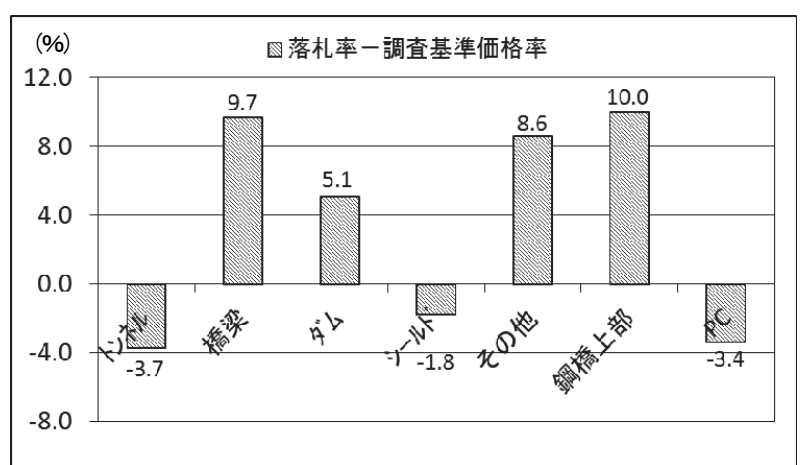

図-5＼cjkstart発注区分ごとの（落札率一調査基準価格率）

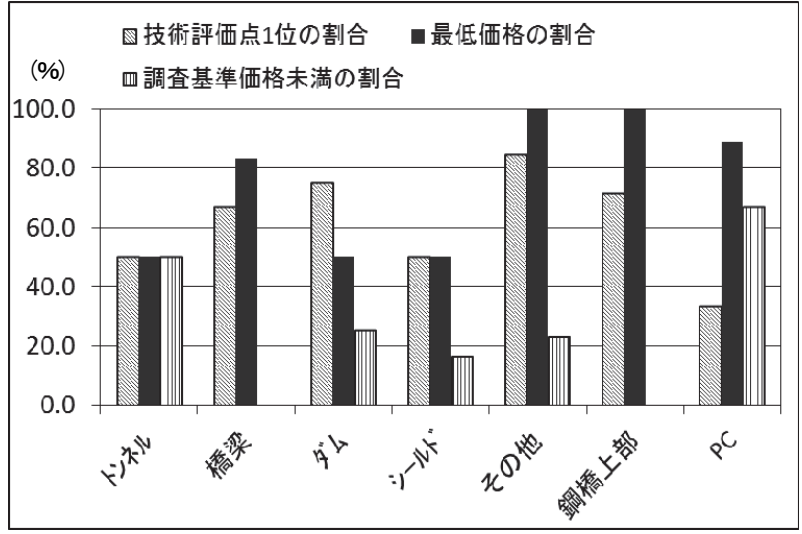

図-6＼cjkstart発注区分ごとの落札者分類の割合 
ンネルとPCにおいては, 落札者に占める調査基準価格 未満の割合が他工種に比べて大きく, 技術評価点1位の 割合が他工種に比べて小さいことが分かる．落札者に 占める最低価格の割合は，（落札率一調查基準価格 率）との関係が確認できない.

\section{（3） 発注区分ごとの傾向（有効参加者数2者以上）}

表-6を基に, 有効参加者数2者以上を調查対象とした 発注区分ごとの分析結果をグラフ化すると図-7，8，9 のとおりとなる.

（落札率一調查基準価格率）が特に小さいトンネル， 及びPCにおいて，技術評価点1位が複数いるケースが確 認されるが，PCなどは11.1\%（9件中1件）のみであり， 技術評価点1位が複数者いるケースが多いことが落札率

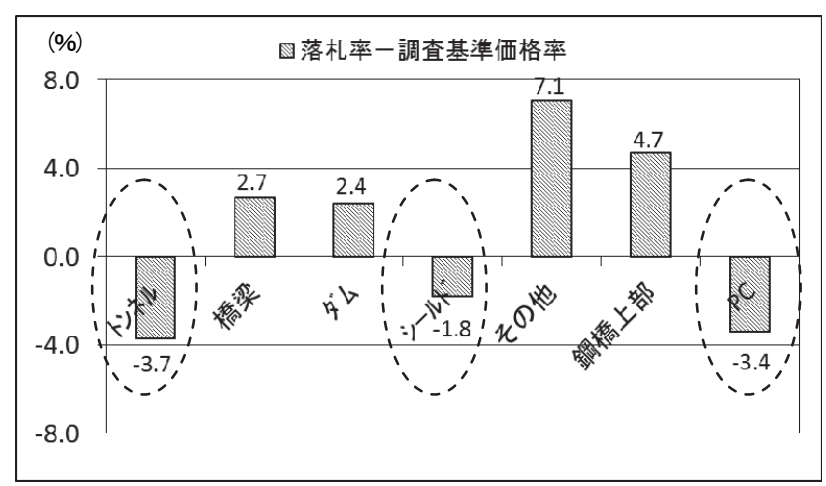

図-7 発注区分ごとの（落札率一調查基淮価格率)

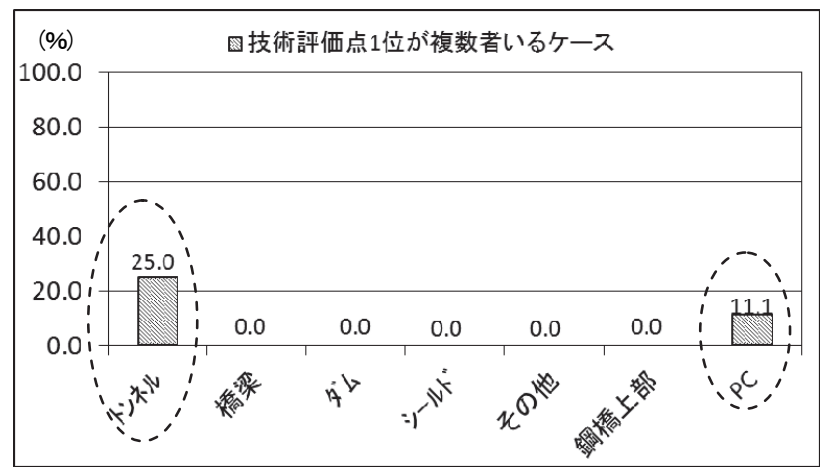

図-8＼cjkstart発注区分ごとの技術評価点1位が複数者いる割合

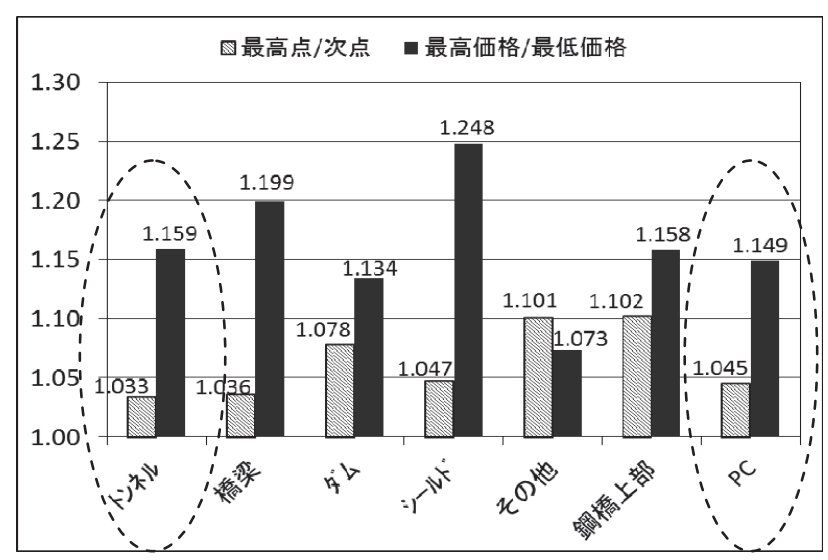

図-9 発注区分ごとの（最高点次点）（最高価格/最低価格）
の低下につながっているとまでは言えない，

一方，図-7と図-9を見比べると，（落札率一調査基準 価格率）がマイナスとなっているトンネル，シールド， 及びPCにおいては，(最高点/次点）が（最高価格/最 低価格）より小さく，その差が他工種に比べて大きい ことが分かる.

前述のとおり，「（技術評価点 $\mathrm{A} /$ 入札価格A）> (技術評価点 $\mathrm{B} /$ 入札価格 $\mathrm{B}) 」 \Leftrightarrow\ulcorner （$ 技術評価点 $\mathrm{A} /$ 技 術評価点B）>(入札価格A/入札価格B）」という計算 式が成り立つことに着目寸ると，例えば，その他工事 においては（最高点/次点）が（最高価格/最低価格） より大きくなっていることから，最高点を獲得した者 が最高価格で応札していたとしても落札できる可能性 が高いという入札競争状態の傾向を読み取れる.

逆に，トンネル，シールド，及びPCにおいては，最 高点を獲得することの落札に対する優位性が比較的低 く, 価格勝負の要素が強いことが分かる. 他工種と比 べると，（最高価格/最低価格）が大きいとは言えない が，（最高点/次点）が小さいという特徴が確認でき, そのことが上記状況の原因の一つであることが分かる.

\section{（4） WTO標準型との比較}

高度技術提案型とWTO標準型との比較を表-7に示す. まず，「落札者に占める技術評価点1位の割合」が高 度技術提案型の方がWTO標準型より小さいことが分か る. 逆に，「落札者に占める最低価格の割合」は高度 技術提案型の方が大きくなっている.

一方，（最高点/次点）と（最高価格/最低価格）の

表-7 WTO標準型との比較（全件対象）

\begin{tabular}{|c|c|c|c|}
\hline \multirow{2}{*}{ 分析項目 } & \multicolumn{2}{|c|}{$\begin{array}{c}\text { 高度技術提案型 } \\
\text { 全期間 } \\
\end{array}$} & \multirow{2}{*}{$\begin{array}{c}\text { WTO標淮型 } \\
\text { H22年度 } \\
\text { (73件) }\end{array}$} \\
\hline & $\begin{array}{l}\text { 全件 } \\
\text { (53件) }\end{array}$ & $\begin{array}{c}\text { 有効2者以上 } \\
\text { (38件) }\end{array}$ & \\
\hline 参加者数 & 5.1者 & 6.3者 & 22.8者 \\
\hline 無効者数 & 0.5 者 & 0.6者 & 5.3者 \\
\hline 不参加 - 辞退者数 & 0.1 者 & 1.1者 & 0.3 者 \\
\hline 予定価格超過者数 & 1.0者 & 0.1 者 & 0.2 者 \\
\hline 有効参加者数 & 3.5者 & 4.5者 & 17.0者 \\
\hline $\begin{array}{c}\text { 1位が複数者いる } \\
\text { ケース }\end{array}$ & $5.7 \%$ & $7.9 \%$ & $45.8 \%$ \\
\hline 最高点次点 & 一 & 1.060 & 1.034 \\
\hline 最高価格/最低価格 & - & 1.157 & 1.069 \\
\hline (a)落札率 & $84.5 \%$ & $81.4 \%$ & $87.1 \%$ \\
\hline (b)調査基淮価格率 & $80.9 \%$ & $81.3 \%$ & $85.9 \%$ \\
\hline (a)-(b) & $3.6 \%$ & $0.1 \%$ & $1.2 \%$ \\
\hline 技術評価点1位 & $62.3 \%$ & $47.4 \%$ & $81.9 \%$ \\
\hline 最低価格 & $79.2 \%$ & $71.1 \%$ & $27.4 \%$ \\
\hline 調査基淮価格未満 & $28.3 \%$ & $39.5 \%$ & $0.0 \%$ \\
\hline
\end{tabular}


差は高度技術提案型の方が大きくなっており，このこ とも上記落札結果の原因の一つであると推察される.

特に, 「最高価格/最低価格」の分析結果において両 型間の差が大きいが，高度技術提案型では，WTO標準 型に比べて調查基準価格未満の入札が多いこと, 及び 技術提案内容ごとに設計数量が異なることから, 入札 価格の分布幅が広くなっていると考えられる.

高度技術提案型において調查基準価格未満の入札が 多いという点については，予定価格が基本的に技術評 価点の最も高い技術提案に基づき算定されており，入 札参加者が調査基準価格を推測することが難しいこと， 及び施工体制確認型の適用件数が少なく $(11.3 \%) ，$ か つ適用された工事においても調查基準価格未満の落札 があることから, 調查基準価格を下回らない入札をし ようという入札参加者の意識がWTO標準型に比べて低 いことがその原因として考えられる.

\section{6. おわりに}

本研究では, 高度技術提案型における入札競争の現 状を確認することを目的とし, 国土交通省発注工事の うち平成18年度〜平成22年度に公告された高度技術提 案型適用工事（一般土木，鋼橋上部，及びPC）を対象 に, 入札調書を統計分析することで, 入札結果の傾向 を明らかにした。

分析の結果，以下のことが分かった.

・ 入札結果の傾向について, 適用件数が少ないため に年度ごとの推移には一定の傾向が見られないが， 工種ごとに特徵があることが分かった。

- 一般土木のトンネル工事, シールド工事, 及びPC においては, 調査基準価格未満における価格競争 が生じており, 他工種に比べて価格勝負の要素が 強いことが分かった。

既往研究のうち牧角, 田中（2007） 4)におて工 事種別による入札状況の分析が行われているが， そこでは「PCや鋼橋上部工においては，原価割れ に相当する価格帯での競争が激しく, 厳しい受注 環境下にあることがわかった」とまとめられてい る. 本研究の分析結果と違いがあるが, その主な 原因は, 牧角, 田中 (2007) 4)は総合評価方式によ る一般競争入札の寸べてを分析対象とし, 本研究 は高度技術提案型のみを分析対象としているとい う点にあると考えられる。

・さらに, これら3工種における入札競争状態の特徵 として,「参加者数が他工種に比べて多い」, 及 び「（最高点次点）が他工種に比べて小さい」と いう2点が挙げられることが分かった。

- WTO標準型と比べて, 落札者に占める技術評価点1
位の割合は小さく, 最低価格の割合は大きいこと が分かった．高度技術提案型の方が「最高点/次 点」と「最高価格/最低価格」の差が大きいことが, その原因の一つであると推察された.

上記の分析結果を基にすれば，「最高点/次点」が大 きくなれば，落札率は上がり，落札者に占める技術評 価点1位の割合が大きくなると推察される.

高度技術提案型総合評価方式が応札者の技術提案を 求め価值の高い工事の実現を目的としている観点から 考えると, 現状の制度・運用は見直す必要があると思 われる，ただし，制度の見直しにあたっては，多様な 観点からの検討を行う必要があることは言うまでもな い.

なお，本論文は，主執筆者である嵩直人が東京大学 大学院において受託研究員として研究した成果を基に 作成したものである.

謝辞 : 本論文の執筆にあたり，国土交通省道路局企画 課道路事業分析評価室の石原室長，国土交通省国土技 術政策総合研究所総合技術政策研究センター建設マネ ジメント室の森田室長には, 総合評価方式の制度設計 に関する考え方をご教示いただくなど，ご多忙中にも 拘らず大変丁寧なご指導を頂戴致しました. 国土交通 省大臣官房技術調查課の久保係長，国土交通省国土技 術政策総合研究所総合技術政策研究センター建設マネ ジメント室の多田研究官には，入札調書の収集等にお いて多大なるご協力をいただいきました，皆様のご指 導, 及びご協力に対して, 厚く御礼申し上げます.

\section{参考文献}

1) 公共工事における総合評価方式活用検討委員会 : 第 14 回 議事要旨, pp.1, 2008.

http://www.nilim.go.jp/lab/peg/siryou/sougou/iinkai/14_gi jiyoushi.pdf

2) 日経 BP 社：日経コンストラクション, No.492, pp.38-59, 2010.

3）木下賢司：総合評価方式の意義と運用改善に向けた 実務的アプローチについて, 第 24 回建設マネジメン 卜問題に関する研究発表・討論会講演集, pp.53-56, 2006.

4) 牧角龍憲, 田中徹政：落札指標を用いた国直轄工事 における一般競争入札状況に関寸る分析, 建設マネ ジメント研究論文集，Vol.14，pp.191-198， 2007.

5) 牧角龍憲, 田中徹政: 工事等級別にみた総合評価方 式における入札傾向とエネルギーロス, 第 26 回建設 マネジメント問題に関する研究発表・討論会講演集, pp.123-126, 2008.

6) 金子雄一郎，本橋純，島崎敏一: 公開入札情報を用 いた総合評価方式の実態分析, 建設マネジメント研 究論文集, Vol.15, pp.273-280, 2008.

7）松村吉晃, 金子雄一郎, 島崎敏一: 公共工事入札に おける落札率の変動要因の分析, 第 28 回建設マネジ 
メント問題に関する研究発表・討論会講演集, pp.6770, 2010.

8) 塚原隆夫，多田寛，笛田俊治，阿部俊彦，鈴木達 也：公共工事における総合評価方式の実施状況に関
する一考察, 土木学会論文集 F4（建設マネジメン

卜）特集号, Vol.66, No.1, pp.277-284, 2010.

(2011. 9. 30 受付)

\section{ANALYSIS OF BIDDING RESULTS IN PROJECTS TO WHICH TECHNICAL PROPOSAL TYPE OF COMPREHENSIVE BIDDING EVALUATION METHOD IS APPLIED}

\section{Naohito DAKE and Kazumasa OZAWA}

The objective of this paper is to make a statistical analysis on bidding results in projects in 2006 to 2010 to which technical proposal type of comprehensive bidding evaluation method is applied by Ministry of Land, Infrastructure, Transport and Tourism so as to evaluate the current competitive situation. It was found by analytical results that intensive price competition lower than the critical investigation price has occurred especially in projects which are categorized in tunnel construction, shield tunnel construction and prestressed concrete construction. Furthermore, it was revealed that numbers of bidders were more and the difference between the highest score and the second highest one were smaller in above 3 categories of projects than those in the other categories of projects. 